УДК 1(316.77+316.32)

DOI 10.35423/2078-8142.2020.1.2.02

\author{
I. І. Литвиненко, \\ кандидат політологічних наук, \\ дочент кафедри суспільних наук,
} Черкаський факультет Одеськоӥ начіональної юридичної академії, м. Черкаси, Україна e-mail: litvinenkoi@gmail.com ORCID: https://orcid.org/0000-0002-2605-7211

\title{
СОЦІАЛЬНІ МЕРЕЖІ І ТРАНСФОРМАЦІЇ ГЛОБАЛЬНОГО СОЦАЛЬНОГО ПОРЯДКУ
}

Статтю присвячено аналізу ролі соиіальних мереж у становленні глобалізаиійних процесів людства. 3'ясовано, щзо роль соцііальних мереж завжди була важливою у функціонуванні суспільства, однак в останні десятиліття їхній вплив на становлення глобалізаиії суттєво зріс. Глобальний соиіальний порядок виникає, зокрема, завдяки сочіальним мережам. Неостанньою чергою саме завдяки ним він отримує свій сенс, свою ідеологію, своє иіннісне обтрунтування. Глобальний соціальний порядок інституалізується багато в чому завдяки сочіальним мережам. Поступово він сам набуває сочіально-мережевих ознак. У статті проаналізовано соціально-антропологічні підвалини формування специфіки людських сочіальних мереж порівняно із соиіальними зв'язками тварин. Здійснено порівняльний аналіз поглядів Ювала Ноя Харарі, Джеррі Койна, Ніла Фергюсона, Йорана Терборна, Мімеля Мафесолі. Висунуто гіпотезу, що соціальні мережі трансформують зсередини сочіальні інститути, у тому числі ті, щуо становлять інституційний каркас глобалізачії. Водночас, сочіальні мережі суттєво доповнюють функиіонування інститутів у забезпеченні реалізаиії соиіальних потреб членів суспільства.

Ключові слова: сочіальний порядок, глобалізачія, глобальний сочіальний порядок, соціальні мережі, сочіальні ієрархії, сочіальні інститути. 
Чимало хто зауважує, що саме за доби глобалізації набувають поширення соціальні мережі, однак це твердження $є$ справедливим лише почасти. Адже лише соціальні мережі в Інтернет набули вражаючого поширення за останнє десятиліття, але і сам Інтернет $є$ універсальною соціальною мережею, яка вже існує кілька десятиліть. А ще раніше існували широкі соціальні мережі - торгівельні, релігійні, політичні, мистецькі, які також об'єднували людей на рівні горизонтальних зв'язків за принципом не так особистого знайомства, як залучення до спільної справи. Питання варто ставити скоріше інакше: в історії людства завжди існували соціальні мережі, але завдяки інтернету їхня чисельність, обсяг і розмаїття зросли по експоненті. Завдяки такому зростанню вони почали суттєво змінювати саму сутність глобалізації як процесу утворення глобального соціального порядку. 3'ясуванню основних обставин цих змін і присвячена ця стаття.

Щодо історії соціальних мереж варто звернутися, наприклад, до дослідження британського історика Ніла Фергюсона «Площі та вежі», в якому він аналізував вертикальні і горизонтальні соціальні відносини. 3 антропологічного погляду, глобалізація почалася ще десятки тисяч років тому - 3 того часу, як представники Ното Sapiens розселилися по усім континентам (крім Антарктиди) планети Земля. Можна згадати працю ізраїльського дослідника Ювала Ноя Харарі «Людина розумна» [7], послатися на працю американського генетика Джеррі Койна «Чому еволюція правдива» [3], згадати праці інших антропологів чи популяризаторів антропології історія людства почалася не тисячі і навіть не десятки тисяч років тому, а мільйони років тому. За цей час примітивні соціальні зв'язки, властиві соціальним тваринам, поступово трансформувалися у специфічні людські соціальні зв'язки. Можна звернути увагу також на дослідження істориків та представників соціальних наук, які вбачають початок глобалізації у вужчому, більш строгому значенні слова вже у Давньому світі, зокрема у зв’язку з появою світових релігій [5].

Методологією нашого дослідження є ціннісний функціоналізм, який запропонував в якості системного підходу у соціальному пізнанні український дослідник Михайло Бойченко [2]. Цей пі- 
дхід орієнтує на виявлення ціннісного підгрунтя для селекції функціонально успішних стратегій суспільного розвитку.

Якщо Ніл Фергюсон вважає, що перша мережева доба почалася лише у добу Відродження, що він демонструє на прикладі родинно-мережевих зв'язків фамілії Медичі, яка лягла в основу перших міжнародних сталих банківських партнерських зв'язків [6, с. 97-98], то інші дослідники більш оптимістичні щодо витоків глобалізації у людському суспільстві - навіть якщо виходити не 3 антропологічного погляду. Так шведський дослідник Йоран Терборн стверджує, що «Перша хвиля глобалізації - це трансконтинентальне поширення релігій, яке створило те, що ми сьогодні, більш ніж через тисячу років називаємо «світовими релігіями»» [5, с. 62]. Чи можна говорити, що ця хвиля була результатом лише поширення перших імперій, які Фергюсон розглядає як ієрархічні організаційні утворення? Вочевидь, ні. Але перед тим, як перейти до виявлення мережевих засад світових релігій, варто нагадати, що соціально-мережеві зв'язки - це те, що людина частково запозичила у світі природи, у інших соціальних тварин, так само, як запозичила тут і найпростіші ієрархічні соціальні структури і практики.

Ювал Ной Харарі стверджує, що, серед іншого, саме вища соціабельність кроманьйонців сприяла тому, що вони витіснили більш розрізнених і мало згуртованих неандертальців: «Але якщо неандертальці, денисівці та інші види людей не злилися з розумними, чому ж вони зникли? Одна 3 можливих відповідей на це запитання полягає в тому, що Hото sapiens довели їх до вимирання. Уявіть групу розумних, яка досягла Балканської долини, де вже протягом сотень тисяч років жили неандертальці. Новоприбулі почали полювати на оленів, збирати горіхи та ягоди - традиційні продукти харчування корінних мешканців. Завдяки кращій техніці та неперевершеним соціальним навичкам розумні виявилися вправнішими мисливцями та збирачами. Тому вони швидко плодилися та розмножувалися» [7, с. 30-31]. Наскільки таке твердження є науковим, можна ще сумніватися. У будь-якому разі Джеррі Койн відзначає: «Деякі сучасні мислителі розробили складні теорії, згідно $з$ якими наше почуття моральності і багато моральних постулатів виникли в результаті природного добору за способом мислення, 
успадкованим нами від соціального примата - так само, як мова уможливила створення складного суспільства і культури. Проте в кінцевому підсумку ці ідеї зводяться до неперевірених спекуляцій, які, напевно, навіть неможливо перевірити... Я дотримуюсь погляду, що висновки про еволюцію людської поведінки повинні базуватися на дослідженнях не менш прискіпливих, за дослідження інших тварин» [3, с. 243-244].

Справді, Харарі є більше популяризатором, ніж науковцем. Його думка нерідко біжить попереду фактичного обгрунтування, цікаві, хоч до кінця і не обгрунтовані гіпотези для нього частогусто важать більше, ніж доведені статечні теорії. Утім, деякі його ідеї заслуговують на більш докладну перевірку - i то не лише на емпіричну, а й на логічну, а також на постановку мисленнєвих експериментів. Наприклад, надзвичайно цікавим є його припущення про роль і цільову причину розвитку фантазії і абстрактного мислення у Homo sapiens на відміну від інших гомінінів: не утилітарна вітальна потреба, і не рандомна потреба попліткувати пояснюють бурхливий розвиток здатності до абстрактного мислення, «однак фантазії дали нам можливість не просто уявляти якісь речі, але робити це колективно... Розумні ж співпрацюють дуже гнучко 3 незчисленною кількістю чужих людей. Ось чому розумні правлять світом, тоді як мурахи їдять наші рештки, а шимпанзе сидять у клітках у зоопарках та дослідних лабораторіях» [7, с. 39]. Таким чином, еволюціоністи пояснюють особливими соціальними та залежними від них когнітивними якостями глобальне домінування людини як біологічного виду. Це є базовим глобальним соціальним порядком, однак він не пояснює, як саме влаштований цей порядок, так би мовити, всередині людства.

Якщо брати давні часи, Харарі стверджує, що навряд чи можна дати однозначну відповідь на це питання: «... вчені не можуть дійти згоди навіть щодо основних питань, таких як існування приватної власності, малих родин та моногамних стосунків. Відносини в деяких з них могли бути ієрархічними, напруженими та жорстокими, неначе в найогиднішій групі шимпанзе, тоді як в інших невимушеними, мирними та розпусними, неначе у зграї бонобо» $[7$, c. 78]. 
Це останнє питання ставить, зокрема, Ніл Фергюсон, даючи двоєдину відповідь - завдяки побудові соціальних ієрархій і завдяки творенню соціальних мереж. Нас у даному разі більше цікавить друга складова його відповіді. Звісно, варто при цьому пам'ятати, що всі організаційні зусилля є лише виразом об'єктивних людських потреб у спілкуванні на міжнародному і глобальному рівнях, а тому ієрархії чи мережі, чи інші формальні чи неформальні організації будуть лише інструментом глобалізації, а не самою глобалізацією.

Фергюсон узагальнює дані різних спеціальних соціальних наук, таких як економіка, соціологія організаційна поведінка тощо і доходить кількох важливих висновків. По-перше, соціальні мережі - це зовсім не обов'язково невеликі соціальні утворення, нерідко вони охоплюють великі соціальні маси людей. Останнє є особливо властивим цифровій добі, коли контакти між людьми по всьому світу значно спростилися завдяки сучасним засобам масової комунікації та засобам поширення інформації [6, с. 53-64]. Мережа - це не одна невелика структура, нерідко мережі мають кілька центрів, довкола яких утворюються ще більше менших центрів та подекуди утворюються щільні кластери більш інтенсивної взаємодії: «Три найважливіші мірила у формальному аналізі мереж це центральність за ступенем, центральність за посередництвом та центральність за близькістю» [6, с. 56]. Перша центральність визначається кількістю прямих зв'язків особи з іншими представниками мережі, остання 3 інтенсивністю контактів у мережі, а от центральність за посередництвом позначає вагомість внутрішньо мережевих зв'язків - чи переважають контакти 3 центральними фігурами мереж, чи 3 периферійними: «Постаті, яким властива значна центральність за посередництвом, необов'язково повинні мати найбільшу кількість зв'язків, але їхні зв'язки - впливові» [6, с. 57]. Таким чином, у мережах, на відміну від ієрархій, на перший план виходять горизонтальні соціальні зв'язки, а вертикальні відносини ієрархії переосмислюються у «горизонтальних» стосунках центру і периферії, впливів, а не наказів, вузлів, а не керівників: «... що більша кількість вузлів у мережі, то більше користі від мережі отримують всі вузли» [6, с. 62]. 
Дуже цікавою є ідея про спорідненість функціонування соціальних мереж і поширення так званих «вірусних» ідей: «Ідеї (а насправді ще й емоційні стани і стани здоров'я, як-от ожиріння) можуть розходитися соціальними мережами, вельми подібно до того, як передаються справжні віруси» [6, с. 62]. За цього вузли комунікації у соціальних мережах можуть виконувати подвійну роль: як посилювати поширення ідей всередині мережі, так і ослаблювати таке поширення, якщо певний вузол зупиняє таке поширення як шкідливе.

Утім, теорія мереж доволі швидко у своєму розвитку засвідчила, що мережі не є абсолютною альтернативою ієрархій. Так, на прикладі функціонування інформаційних мереж, стало зрозуміло, що деякі вузли, які забезпечують безальтернативно доступ до подальших контактів за межами внутрішньої мережі - інформаційні хаби - $є$ не лише вузлами, а й своєрідними «рубильниками», які можуть повністю перекрити зовнішній доступ, а тому займають безперечно вищий ієрархічний статус усередині самої мережі. Хоча коли хаб включений, виникає ілюзія повної свободи і легкої доступності усіх контактів всередині мережі.

Приклад з інформаційними мережами багато у чому є показовим для розуміння функціонування усієї глобалізації людства: коли немає значних загроз виникає відчуття повної прозорості суспільства у глобальному масштабі - подорожуй куди хочеш, спілкуйся 3 ким хочеш, веди бізнес 3 ким хочеш тощо. Однак, сучасна пандемія ковід-19 показала, наскільки крихкою і умовною $є$ така ілюзія перемоги глобалізації над локальними соціальними структурами: кордони легко закриваються, міжнародні проекти якщо не згортаються зовсім, то нерідко надовго відтерміновуються або значно скорочуються. Однак саме багатоманітність глобальних соціальних мереж, яка значно перевищує багатоманітність глобальних формальних організацій (як от ООН, Світовий банк, Юнеско тощо), гарантує те, що навіть якщо розглядати глобалізацію не як об'єктивний процес, але як проект, тоді «закрити» глобалізацію буде практично неможливо - доти, доки люди зацікавлені комунікувати у глобальних масштабах.

Водночас, приклад інформаційних мереж засвідчує, що глобалізація завжди організаційно є складною не лише якісно, а й за 
рівнями організації комунікації. Окремі соціальні мережі виникають довкола різних цінностей, так що інколи цінності однієї мережі виявляються не сумісними 3 цінностями іншої. Однак завжди знаходяться окремі представники обох таких ворожих спільнот, які або примудряються бути одночасно їхніми членами, або, частіше, знаходять третю спільноту, до якої вони також входять, яка є ціннісно нейтральною щодо перших двох. Наприклад, Ромео і Джульєта кохали одне одного попри ворожнечу їхніх сімей: їхнє почуття не базувалося на сімейних традиціях, але йшло своїм власним шляхом. Так само у міжнародних відносинах навіть на інституційному рівні зовсім нерідко зустрічаються на перший погляд парадоксальні і майже неможливі коаліції, а на рівні соціальних мереж долання здавалося би нездоланних організаційних кордонів, своєрідна організаційна трансгресія є швидше нормою, ніж винятком. Цілком логічно припустити, що нерідко соціальні мережі виникають саме там, де інші, переважно формальні соціальні організації виявляються надто структурно і нормативно жорсткими, а комунікативні потреби у людей через це виявляються нереалізованими. Але в історії людства нерідко траплялися ситуації, коли, навпаки, саме соціальні інститути утворювалися як варіант організаційного закріплення розвинених мережевих зв'язків. Загалом, чим далі розвивається людство, тим більш справедливо не протиставляти соціальні мережі і соціальні ієрархії, соціальні мережі і соціальні інститути, але більш доречно і коректно розглядати їх переважно як різні рівні організації комунікації: соціальні мережі більш ефективно діють на низовому і середньому рівні соціальної комунікації, соціальні інститути, ієрархії та формальні організації - на середньому та вищому рівнях. Хоча, якщо розглядати процес глобалізації як ціле, він швидше нагадує мобільну і гнучку, не завжди передбачувану над-мережу, ніж якусь добре структуровану і надійно заплановану над-організацію.

Це добре демонструє історія становлення глобалізації. Зокрема, Терборн вирізняє шість хвиль глобалізації: крім уже згаданої нами першої хвилі у IV-VI ст. нашої ери (1), він називає і обгрунтовує європейський колоніалізм XVI - початку XVII століття (2), франко-британську світову війну 1750-1815 рр. та посилення єв- 
ропейської наддержави (3), загальний імперіалізм і світовий поділ на економічно розвинені і економічно відсталі країни у 18301918 pp. (4), глобалізаційну політику у 1919, 1941, 1947-1989 роках (5) i, нарешті, остаточне самоствердження глобалізації з 1990 р. [5, с. 60-84]. 3 одного боку, зрозуміло, що цей автор розглядає глобалізацію як дедалі більш планово здійснюваний проект, в якому ієрархії явно домінують над мережами. 3 іншого боку, дослідник засвідчує, що культура і менталітет глобалізації формувалися невпинно і без усякого спеціального керівництва протягом майже всієї історії людства (на прикладі аналізу економічних, демографічних, вікових, генераційних, гендерних, культурних та інших процесів). Усе це дає підстави стверджувати, що інституційні засади глобалізації не меншою мірою завдячують впливу соціальних мереж, ніж тиску соціальних ієрархій.

Щодо невиправданої переоцінки свідомого планування соціальних процесів, а також виявлення поза-раціональних впливів на суспільний розвиток доволі показовим i переконливим є дослідження норвезького і американського політолога Юна Ельстера «Кислий виноград», в якому він аналізує особливості колективного вибору, в котрому дедалі більшу роль відіграє не раціональність, а особиста свобода, яку ідеалізує чимало теоретиків, виявляється надто переоціненою [8]. Французький філософ Мішель Маффесолі дає оригінальну відповідь, яка наближає нас до розв'язання проблеми мереж: у сучасному суспільстві, яке свідомо позиціонує себе як глобальне за визначенням, на перший план суспільного життя виходять соціальні спільноти, які базуються не на раціональних проектах, а переважно на спільних емоціях. Це - своєрідний новий трайбалізм, коли дедалі більшою мірою життєво важливі рішення приймають саме колективно, у режимі, так би мовити, спільної «атмосфери», а не за моделлю Просвітництва. Маффесолі підводить до думки, що такі спільноти-триби нікуди не зникали з первісних часів, просто мінялися засади їхнього утворення, змінювалися цінності, а самі спільноти приховувалися за лаштунками, давши можливість дедалі більшою мірою виступати соло окремим особистостям. У постмодерну добу таке маскування виявилося для спільнот уже непотрібним, і вони знов вийшли на авансцену історії [4]. 
Усе це змушує переосмислити роль соціальних мереж в історії людства загалом і у становленні його глобалізації, зокрема. Для соціальної філософії і ширше - соціальної теорії, стає необхідним переосмислити насамперед засади функціонування соціальних інститутів. Деякі вітчизняні дослідники вже займаються виконанням цього завдання. Так, можна взяти до уваги праці М. Бойченка, наприклад, його дослідження системних засад гуманітарної освіти, в якому він розкриває роль тих чинників, які зазвичай вважали несистемними і неінституційними [1]. У сфері освіти найбільш очевидною виявляється провідна роль соціальних спільнот у функціонуванні соціальних інститутів - зокрема й через функціонування соціальних мереж.

Якщо на перших порах глобалізація здійснювалася доволі планово, під впливом транснаціональних компаній, зразком яких можуть слугувати численні ост-індські компанії, то чим далі, тим більше глобалізація не вписується вже в жодний окремий проект $\mathrm{i}$ стає очевидним, що намагання втиснути іiі в якусь певну схему завжди були і будуть марними. Це зовсім не перекреслює значущості інституційного каркасу, який лежить в основі більшості глобалізаційних процесів: навпаки, інституційні завдання нерідко виконуються у не-інституційний спосіб, що доповнює інституційні шляхи глобалізаційного будівництва.

Соціальні мережі, втім, дедалі більшою мірою 3 доповнювальних засобів соціальної взаємодії перетворюються на базові - у тому числі й всередині самих соціальних інститутів. Соціальні мережі не лише проникають у вже наявні соціальні інститути, а й самі інституалізуються. Так, соціальні мережі в Інтернет давно перетворилися на строго регламентовані у своєму функціонуванні інституції.

Окремо слід згадати особливий зв'язок між соціальними мережами і соціальними системами. Тривалий час вважали, що завдання соціальних систем ідеально виконують формальні організації. Дещо згодом розширили множину можливих виконавців за рахунок соціальних інститутів. Однак більш важливим за однозначністю засобів досягнення системних завдань $є$ однозначність самого такого досягнення. I якщо засоби можна урізноманітнювати, то 
це лише краще відповідатиме базовому принципу функціональної еквівалентності, на який спирається не лише дія, а й саме існування соціальних систем. Адже чим варіативнішим є можливе виконання системних завдань, тим більш гарантованим воно буде - система повинна максимально ефективно адаптуватися до всіх можливих змін свого середовища. Мережевий спосіб такої адаптації, як правило, виявляється більш гнучким і мобільним, ніж інституційні, а тим більше формально-організаційні способи, які спираються на жорсткі правила і заборони.

Підіб'ємо підсумки основних відповідей на ключове питання нашого дослідження: як саме трансформується глобальний соціальний порядок під впливом соціальних мереж? По-перше, глобальний соціальний порядок виникає, у тому числі, завдяки соціальним мережам. По-друге, глобальний соціальний порядок отримує свій сенс, свою ідеологію, своє ціннісне обгрунтування не останньою чергою завдяки соціальним мережам. По-третє, глобальний соціальний порядок інституалізується багато у чому завдяки соціальним мережам. Нарешті, по-четверте, глобальний соціальний порядок сам поступово набуває соціально-мережевих ознак.

\section{ЛITEРАТУРА}

1. Бойченко М. Застосування системного підходу в гуманітарній освіті. Гуманітарна педагогічна парадигма вищої освіти. Київ : Педагогічна думка, 2007. С. 49-66.

2. Бойченко М. Соціальні цінності і функціональні завдання освітньої комунікації: філософське осмислення. Гілея: науковий вісник. Збірник наукових праць. Київ : ВІР УАН, 2017. Вип. 116. С. 233-240.

3. Койн Дж. Чому еволюція правдива / пер. 3 англ. Т. Цимбала. Киїі : Наш Формат, 2015.

4. Маффесолі М. Час племен. Занепад індивідуалізму у постмодерному суспільстві / пер. $з$ фр. В. Плющ. Київ : ВД «Києво-Могилянська академія», 2018.

5. Терборн Й. Мир. Руководство для начинающих / пер. с. англ. Е. М. Горбуновой, Л. Г. Титаренко. Москва: Изд. дом Высшей школы экономики, 2015.

6. Фергюсон Н. Площі та вежі. Соціальні зв'язки від масонів до фейсбуку / пер. з англ. К. Диса. Київ : Наш формат, 2018. 
7. Харарі Ю. Н. Sapiens. Людина розумна. Історія людства від минулого до майбутнього / пер. $з$ англ. Я. Лебеденка. Харків : Книжковий клуб «Клуб сімейного дозвілля», 2016.

8. Эльстер Ю. Кислый виноград. Исследование провалов рациональности / пер. с англ. И. Кушнаревой. Москва : Издательство Института Гайдара, 2018.

\section{REFERENCES}

Boychenko, M. (2007). Application of a systematic approach in humanitarian education. Humanitarian pedagogical paradigm of higher education. Kyiv: Pedahohichna dumka, pp. 49-66. [In Ukrainian].

Boichenko, M. (2017). Social values and functional tasks of educational communication: philosophical understanding. Hileya: naukovyy visnyk. Zbirnyk naukovykh prats' (Gileya: scientific bulletin. Collection of scientific works), Issue 116. pp. 233-240. [In Ukrainian].

Coyne, Jerry (2015). Why Evolution is True. T. Tsymbal (Transl). Kyiv: Our Format. [In Ukrainian].

Maffesoli, M. (2018). Age of tribes. The decline of individualism in postmodern society. French V. Pliushch (Transl). Kyiv: VD "Kyiv-Mohyla Academy". [In Ukrainian].

Therborn, Joran (2015). The World: A Beginner's Guide. E. M. Gorbunova, L. G. Titarenko (Transl). Moscow : Izd. the house of the Higher School of Economics. [In Russian].

Ferguson, Neil (2018). Squares and towers. Networks and Pover: from the Freemasons to Facebook. K. Dis. Kyiv: Our format. [In Ukrainian].

Harari, Yuval Noah (2016). Sapiens. A Brief History of Humankind from the past to the future. Ya. Lebedenko (Trans.). Kharkiv : Book Club "Family Leisure Club". [In Ukrainian].

Elster, Yon (2018). Sour grapes. Studies in the Subversion of Rationality. I. Kushnareva (Trans.). Moscow: Gaidar Institute Publishing House. [In Russian]. 


\section{Iryna Litvinenko}

PhD in Political Sciences, Associate Professor of Social Sciences, Cherkasy faculty of the Odessa National Law Academy; Cherkasy, Ukraine; e-mail: litvinenkoi@gmail.com; ORCID: https://orcid.org/0000-0002-2605-7211

\section{Social networks and transformations of the global social order}

\section{Abstract}

The article is devoted to the analysis of the role of social networks in the formation of globalization processes of mankind. It has been found that the role of social networks has always been important in the functioning of society, but in recent decades their influence on the formation of globalization has increased significantly. The global social order arises, in part, through social networks. The global social order gets its meaning, its ideology, its values, not least through social networks. The global social order is institutionalized largely through social networks. The global social order itself is gradually becoming socially networked. The socio-anthropological foundations of the formation of the specifics of human social networks in comparison with the social connections of animals are analyzed. Network theory has shown fairly quickly that networks are not an absolute alternative to hierarchies. Thus, on the example of the functioning of information networks, it became obvious that some nodes that provide access to further contacts outside the internal network - information hubs - are not just nodes, but a kind of "switches" that can completely block external access, and therefore occupy undoubtedly the highest hierarchical status within the network itself. Although when the hub is turned on, there is an illusion of complete freedom and easy availability of all contacts within the network. The modern Covid-19 pandemic has shown how fragile and conditional this illusion of globalization's victory over local social structures is: borders could be easily closed, and international projects, if not completely curtailed, could be often delayed or significantly reduced. However, it is the diversity of global social networks that far exceeds the diversity of global formal organizations (such as the UN, the World Bank, UNESCO, etc.) that ensures that even if we consider globalization not as an objective process but as a project, then "close" globalization will be virtually impossible - as long as people are interested in communicating on a global scale. A comparative analysis of the views of Yuval Noah Harari, Jerry Coyne, Neil Ferguson, Yoran Therborn, Michel Maffesoli. It is hypothesized that social networks transform social institutions from within, including those that make up the institutional framework of globalization. On the other hand, social networks significantly 
ISSN 2078-8142 Multiversum. Philosophical almanac. 2020. Issue 1(171). Vol. 2.

complement the functioning of institutions in ensuring the implementation of social needs of members of society.

Keywords: social order, globalization, global social order, social networks, social hierarchies, social institutions. 